Board of Governors of the Federal Reserve System

International Finance Discussion Papers

Number 694

December 2000

\title{
FISCAL FEDERALISM AND EUROPEAN INTEGRATION: IMPLICATIONS FOR FISCAL AND MONETARY POLICIES
}

\author{
Edward M. Gramlich and Paul R. Wood
}

NOTE: International Finance Discussion Papers are preliminary materials circulated to stimulate discussion and critical comment. References in publications to International Finance Discussion Papers (other than an acknowledgment that the writer has had access to unpublished material) should be cleared with the author or authors. Recent IFDPs are available on the Web at www.federalreserve.gov/pubs/ifdp/. 


\title{
FISCAL FEDERALISM AND EUROPEAN INTEGRATION: IMPLICATIONS FOR FISCAL AND MONETARY POLICIES
}

\author{
Edward M. Gramlich and Paul R. Wood
}

\begin{abstract}
This paper examines European economic integration in light of standard thinking about fiscal federalism. We first describe the main features of European integration, analyzing how institutions in the European Union fit the prescriptions of a federal system. We find that in some areas the European Union has already developed arrangements that fit standard views of fiscal federalism, in other areas there is gradual movement toward prescribed arrangements, and in still other areas the European Union's unique historical path may suggest some interesting new departures in the federalism literature. We try to extract some lessons from this analysis: some recommendations for Europe based on the orthodox principles of fiscal federalism, and some modifications of these orthodox principles based on the European experience.
\end{abstract}

Keywords: fiscal federalism, European Union, tax harmonization, fiscal policy

* Gramlich is a member of the Board of Governors of the Federal Reserve System and Wood is an economist in the International Finance Division of the Board of Governors of the Federal Reserve System. We would like to thank Carol Bertaut for help in writing the monetary policy section of this paper and Tim Troha for excellent research assistance. We appreciate helpful comments from Joseph Gagnon, David Howard, Karen Johnson, Steven Kamin, and Linda Kole. This paper was written for inclusion in the book: "Fiscal Federalism and European Integration," edited by Mark Baimbridge and Philip Whyman, Routledge Press, 2001. The views in this paper are solely the responsibility of the authors and should not be interpreted as reflecting the views of the Board of Governors of the Federal System or of any other person associated with the Federal Reserve System. Corresponding author: paul.wood@ frb.gov 


\section{Introduction}

Fiscal federalism has been an important economic topic for many years now. The usual analysis of fiscal federalism has considered various expenditures and taxes, asking which expenditure and tax programs should be carried out by what level of government. However, the more fundamental question regarding the shape of the nation, or federation, is typically not asked.

European economic integration raises this interesting and fundamental question.

Depending on whether one is looking at the European Union (EU) or the euro area, either fifteen or eleven (soon twelve) viable economic states have come together and formed a new union, certainly the most significant such union in modern economic history. Instead of dealing with the assignment of spending and taxing programs between various levels of government, the Europeans are now considering situations where national governments are giving up some authority to the newly-formed overall confederation. Analyzing such an important change greatly enriches the study of federalism. Now questions involving the power that is given up, how it is managed at the new central level, and what other accommodations are to be made are all in play.

In this paper we examine European economic integration in light of standard thinking about federalism. We first describe the main features of European integration, analyzing how these institutions fit the main prescriptions of a federal system. On some issues the Europeans have already developed reasonably satisfactory arrangements, on others they have a way to go, and on still others their unique historical path may suggest some interesting new departures in the federalism literature. We then try to extract some lessons from this analysis: some recommendations for Europe based on the orthodox principles of fiscal federalism, and some modifications of these orthodox principles based on the European experience. 


\section{Institutional Description}

In contrast to the mature federations contemplated in the standard theory of fiscal federalism, the EU is not a federation but a confederation of fifteen national governments. The EU central government is small and derives most of its authority indirectly through the national governments rather than through direct elections. The directly elected European Parliament has a very limited role in governing the EU. The principal power of the EU's government rests with the Council of the European Union (the Council), which is not directly elected but consists of one representative at the ministerial level from each member government. The European Commission (the Commission) is the executive organ of the EU, advising the Council and implementing its directives.

Given this structure, the EU features a relatively restricted role for the central authority. Among policies that are determined centrally, monetary policy is probably the most important. That is set by the European System of Central Banks. Only eleven (twelve as of January 2001) of the fifteen EU member states are part of the euro common currency area. The eventual goal is to include all fifteen EU member states in the euro area, as well as to include new EU members as soon as practical after their accession. Denmark's recent rejection of the euro may call into question this goal.

The Maastricht Treaty set conditions for the adoption of the common currency by member countries. Inflation rates and long-term interest rates were required to converge toward the average rates in the three best-performing member countries. National governments also were required to bring budget deficits and debt down to acceptable levels, or to show that they were making significant progress toward achieving those goals. The fiscal requirements stemmed from a concern that, under monetary union, the fiscal policy of one country would have an impact on other countries. First, there was a fear that large budget deficits and debts in one country would 
drive up interest rates for other countries within the monetary union. Second, large fiscal deficits for the area as a whole could undermine the credibility of the new central bank, to the extent that monetary policy might pressured into accommodating overly loose fiscal policy. Finally, there was a concern that market participants might assume that the EU would bail out a country in severe financial difficulties.

The Stability and Growth Pact (SGP) was adopted in 1997 to ensure that fiscal discipline would be a continuing part of Economic and Monetary Union (EMU). Under the SGP, each country in the euro area must submit a stability program, while each country in the broader EU must submit a convergence program. These programs give targets over the medium term (typically the next four years) for the budget balance and debt. The Commission reviews each program and makes a recommendation to the Council, which then delivers an opinion on each program and can ask a member country to alter its targets.

The Council and the Commission monitor the implementation of the stability programs to ensure that member country governments do not diverge significantly from the stated targets. Because the budget balance targets are not set in cyclically-adjusted (or structural) terms, a significant worsening of economic performance and tax revenues relative to that assumed in the program can force a national government to tighten its fiscal stance in order to meet the program objectives. Partly in response to that possibility, the economic assumptions embedded in the stability programs tend to be on the conservative side. That presents a problem of a different sort. If economic performance is stronger than assumed, a national government can ease its fiscal stance and still meet its stated objectives. In both scenarios, the focus on budget balance targets can create incentives for pro-cyclical fiscal policy. 


\section{Spending Policies}

The theory of fiscal federalism concludes that, in the absence of significant externalities or economies of scale, spending programs should be carried out at the lowest level of government possible. In this way spending programs can respond to local concerns and conditions and take account of regional taste differences. But because factors of production are typically mobile across state borders, taxation programs should be conducted at the highest level of government possible, to cut down on tax competition between local authorities that could lead to sub-optimal levels of service provision. The difference between high local expenditures and low local taxes, and low central expenditures and high central taxes, is to be made up by central government grants to local governments.

Largely for historical reasons, the EU appears to fit this prescription on the spending side, though not on the tax or grant side. The EU budget is very small relative to that of central government budgets in the fifteen member states and in other Organization for Economic Cooperation and Development (OECD) countries. EU central government outlays were restricted by agreement to only $1.27 \%$ of EU GDP for the $2000-2006$ period, and the EU also has very little discretion over this spending.

The largest single central spending program is in connection with the Common Agricultural Policy, a program designed to stabilize and support farm incomes. Another type of EU spending is aimed at facilitating the growth of a single market and helping poorer regions that are left behind. To that end, there are several funds that are collectively called the Structural and Cohesion Funds. These funds are used to develop infrastructure and promote adjustment in regions that are lagging in development or that are facing structural difficulties. These funds are not primarily geared towards redistribution as such, and their small size prevents them from doing 
much to address economic inequalities, within or across countries. These funds also do not play any role in stabilizing against asymmetric spending shocks, a topic we discuss below.

The EU does not have spending programs in many of the areas that would normally be contemplated for the central government in longer-standing federations. The EU does not provide for such standard central services as national defense, foreign aid, or inter-country highways. There has been some move to give the EU a greater role in coordinating defense and foreign policy, including a suggestion by the French foreign minister that Europe may someday need a single nuclear authority to speak for the EU as a whole in negotiations with other nuclear powers. This is one straw in the wind that suggests that the central government's role in providing standard national goods may gradually increase over time.

In addition, the EU might develop a larger role over time in the redistribution of income among EU countries. But rather than giving the EU government a greater share of revenues, or permitting it to levy its own taxes, the EU may devise a revenue sharing system with its member national governments, similar to that now used within Germany.

If the EU begins to provide more services that are currently funded by national governments, and if it acquires the revenue sources to provide these services, the importance of the present national governments may recede over time. Under orthodox canons of fiscal federalism, services such as primary education, police and fire protection, and local roads, now provided by local governments, should probably stay that way. Services such as national defense and inter-country highways should probably gravitate to the centralized level. This may leave a vacuum at the present national level. It has long been predicted, so far not accurately, that the same vacuum would develop for American states.

One additional area where the EU, even though new, does follow orthodox canons of federalism involves policies related to competition. To nurture an evolving single market, the 
Commission sets competition policy. The goal of that policy is to guarantee that firms can compete on a level playing field throughout the EU. Competition policy also strives to avoid monopolization of markets. Firms are prohibited from making agreements that restrict competition or from abusing a dominant position in a market. The Commission rules on proposed mergers to ensure that they do not impede competition and to decide whether they are compatible with the single market. The Commission also aims to prevent member countries from aiding firms in a way that would distort competition. 


\section{Taxation and Grants}

While the theory of federalism suggests that much taxation authority should be lodged with the central government, the historical development of the EU did not follow that pattern. Member national states were reluctant to surrender too much taxing power to the new confederation. To reduce tax competition, then, the EU has taken the alternative approach of trying to harmonize or coordinate different national taxation systems. The logic is that as far as tax competition goes, the important issue is relative tax rates, not which government actually collects the revenue.

In the EU model, there is in principle limited tax competition and little need for central government grants. Those who fear the rise of government would see at least two advantages in the European model:

- rather than spending most of their time lobbying for grants, member country politicians should actually be managing their budgets;

- to the extent that union power or other forces tend to raise government spending beyond the optimal level, any residual tax competition that follows incomplete standardization will offset the pro-spending distortions.

As for particular taxes, the theory of fiscal federalism provides some guidance about which taxes should be harmonized and which not. Theory suggests that taxes on mobile factors should be harmonized, while taxes on immobile factors need not be. That implies that taxes on mobile capital, including corporate taxes, should be harmonized but that taxes on labor need not be, at least to the same degree. The Value Added Tax (VAT) would fall into the category of taxes on mobile factors, because purchasers can move across the border to make some purchases.

Table 1 below shows, for each of the EU countries, effective tax rates on labor, capital and consumption, as well as standard VAT rates. These effective tax rates (from the European 
Commission) allow us to separate the incidence of the tax burden falling on each factor.

Effective tax rates come from dividing the broad categories of tax revenues by the corresponding tax bases: labor income, capital income, and consumption expenditure. As can be seen from the table, consistent with the idea that less mobile factors would be more heavily taxed in the absence of complete tax coordination, the average tax rate on labor income is greater than that on capital or on consumption. In addition, the standard deviation of effective labor tax rates among EU countries is greater than that for capital tax rates, although the difference is only slight when measured by the coefficient of variation.

As shown by both the standard deviation and the coefficient of variation, consumption tax rates (and specifically VAT rates) appear more closely aligned among EU countries than are tax rates on labor and capital. Consumption is intermediate between labor and capital in terms of mobility. While cross-border shopping can occur in response to significant differences in tax rates, it does not occur to the same extent as cross-border movements of capital. Thus the smaller variation in consumption tax rates than capital tax rates across EU countries may owe less to the mobility of consumption than to efforts by the Commission to coordinate tax policies with respect to consumption. The Commission has proposed minimum standard rates for the VAT and has encouraged a reduction in the number of items that are taxed at reduced VAT rates. 


\section{Table 1}

\section{Tax Rates in EU Countries}

\begin{tabular}{|c|c|c|c|c|}
\hline & $\begin{array}{l}\text { Effective tax } \\
\text { rate on labor }\end{array}$ & $\begin{array}{l}\text { Effective tax } \\
\text { rate on capital }\end{array}$ & $\begin{array}{l}\text { Effective tax rate } \\
\text { on consumption }\end{array}$ & $\begin{array}{l}\text { Standard value- } \\
\text { added tax rate }\end{array}$ \\
\hline Austria & 40.6 & 18.8 & 23.4 & 20.0 \\
\hline Belgium & 44.8 & 23.7 & 20.5 & 21.0 \\
\hline Finland & 43.3 & 24.1 & 24.5 & 22.0 \\
\hline France & 42.4 & 22.6 & 24.5 & 19.6 \\
\hline Germany & 44.0 & 15.9 & 17.9 & 16.0 \\
\hline Ireland & 24.2 & 20.8 & 24.8 & 21.0 \\
\hline Italy & 35.8 & 26.2 & 22.9 & 20.0 \\
\hline Luxembourg & 31.0 & 34.0 & 25.7 & 15.0 \\
\hline Netherlands & 36.9 & 25.1 & 19.5 & 17.5 \\
\hline Portugal & 27.8 & 24.6 & 22.7 & 17.0 \\
\hline Spain & 29.9 & 18.5 & 17.7 & 16.0 \\
\hline Denmark & 44.5 & 28.0 & 30.5 & 25.0 \\
\hline Greece & 29.3 & 19.5 & 20.0 & 18.0 \\
\hline United Kingdom & 25.2 & 35.1 & 18.2 & 17.5 \\
\hline Sweden & 51.3 & 27.9 & 28.0 & 25.0 \\
\hline Average & 36.7 & 24.3 & 22.7 & 19.4 \\
\hline $\begin{array}{l}\text { Standard } \\
\text { Deviation }\end{array}$ & 8.1 & 5.3 & 3.7 & 3.0 \\
\hline $\begin{array}{l}\text { Coefficient of } \\
\text { Variation }\end{array}$ & $22.1 \%$ & $21.6 \%$ & $16.1 \%$ & $15.4 \%$ \\
\hline
\end{tabular}

Source: European Commission, May 2000. 
Capital is mobile enough for tax competition and tax evasion to be serious worries, leading to a presumptive role for the EU in harmonizing capital income tax rates and tax withholding policies. There is a concern that investment will flow to countries with low tax rates, or that taxpayers may escape taxation altogether by investing in a country that does not report the income to the country in which the taxpayer resides. The best solution to this problem is to have full centralization of taxes on mobile factors. The next best is to have full information-sharing among EU countries. The third best is withholding at the source of investment income to reduce the incentive to evade taxes.

There is less labor mobility in Europe than in other countries with a federal structure--the United States, Canada, and Australia. Low labor mobility allows European governments to set labor income taxes and unemployment benefits more freely than would otherwise be the case. But labor mobility, at least among the EU countries, will probably increase over time, making a centralized set of tax rates on labor income potentially more desirable in the future.

The greater mobility of capital than labor has tended to shift EU taxation away from capital and towards labor, as would be predicted by most economic theories. As long as capital is fully mobile, within the EU and indeed outside of its borders, its income cannot be taxed very heavily by any country. Hence this tax shift is fundamentally a result of factor mobility, not of European economic integration or harmonization policies. It would be likely in any country that allows free capital movements. 


\section{Fiscal Policy}

Most discussions of fiscal federalism consider spending and tax programs and end there. The usual thinking is that stabilization policies, monetary and fiscal policy, are best left to the central authority. But that thinking ignores the fact that macroeconomic shocks could be regional, affecting some parts of the federation differently than other parts. If the federation has a common monetary policy, the logical way to deal with differential shocks is through differential fiscal policy.

This is precisely the issue that now confronts the EU. There are clearly differential shocks. These may be less important over time in the EU countries, as they integrate and perhaps become similar economies. But the EU countries will never be producing exactly the same goods, and indeed integration may also increase specialization. For practical purposes, there should at least be planning for a fiscal response to differential shocks.

The following chart provides an illustration of how stabilization needs may vary across member countries at any given point in time. The chart shows, for ten of the euro- zone countries, short-term interest rates implied by a simple Taylor rule that puts equal weights on output gaps (measured by the OECD) and the excess of core inflation over the implicit target rate, which we have assumed to be $1-1 / 2$ percent. The equilibrium real interest rate is assumed to be 3-1/4 percent, which is approximately equal to the twenty-year average for Germany. It is notable that considerable convergence among implied Taylor-rule interest rates has taken place among EMU countries since the Maastricht treaty was signed. However, the chart shows a significant difference even in the most recent year between the Taylor-rule interest rates of the countries most (Ireland) and least (Germany) in need of restraint.

[Insert Chart on Taylor Rule Interest Rates] 


\section{Taylor Rule Short-Term Interest Rates*}

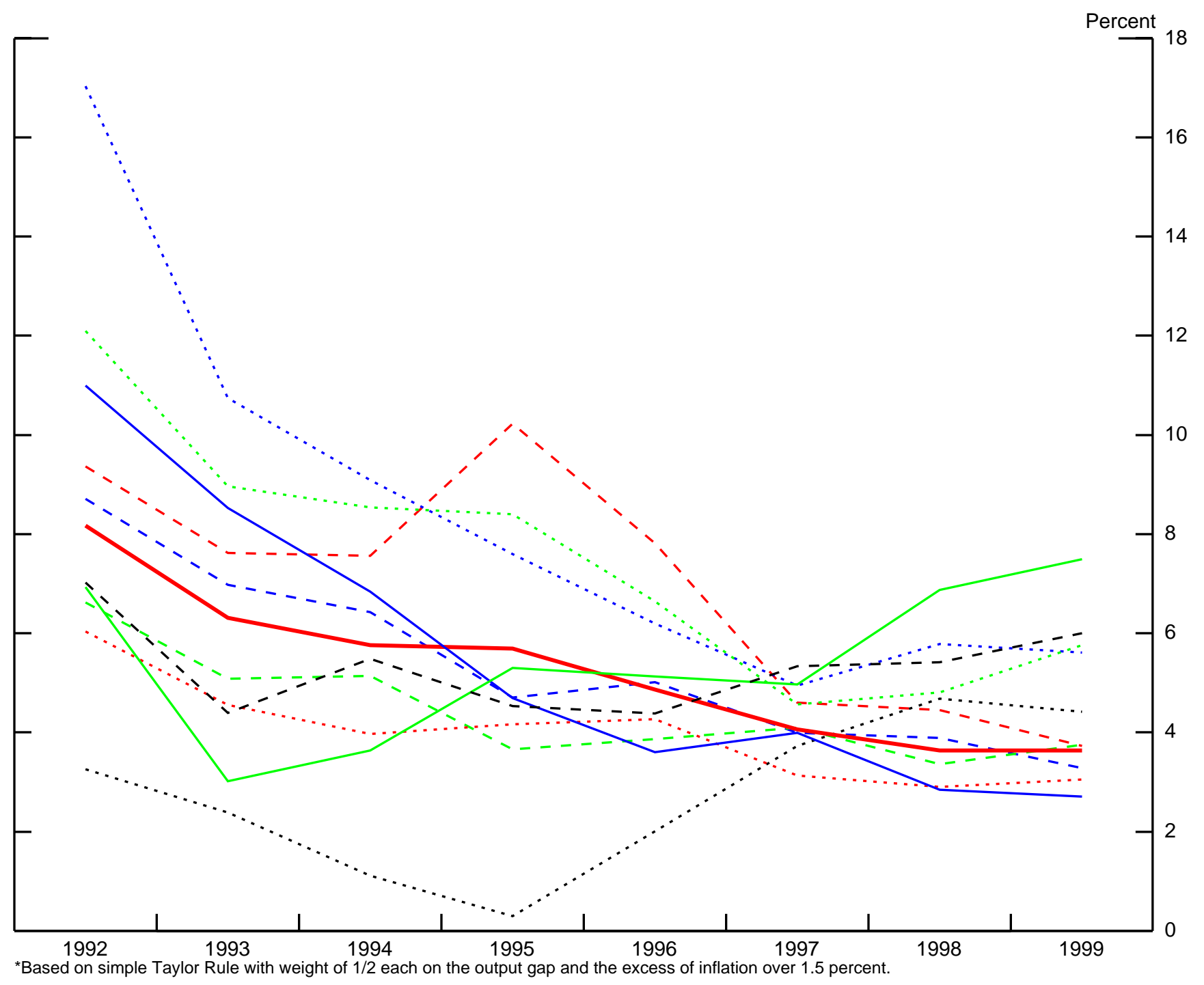

Taylor Rule

for:

- EU-11

- Germany

_ Ireland

- - Netherlands

- - Italy

- - Austria

- - Belgium

... Finland

.... France

... Portugal

... . Spaín 
In principle one can think of several potential natural adjustment mechanisms for differential shocks. Relative prices can change, factors of production can migrate, there can be monetary transfers between regions, or fiscal policies can be different. In the EU, most of the natural adjustment mechanisms seem to be unimportant: relative prices are sluggish, labor mobility is limited, and regional transfers are minimal. This leaves differential fiscal policy as the main means of adjusting for differential shocks.

The small size of the EU budget implies, at least for now, that differential EU fiscal policy will not play a large role in fiscal stabilization. Since national governments will control their much larger budgets, they could in principle act differentially: Those countries with excess demand pressure could tighten fiscal policy and those countries with deficient demand could ease. There is no constitutional bar to such an assumption of stabilizing fiscal policy responsibilities by the component national governments. Unlike state governments in the United States, these national governments do not have constitutional constraints on their ability to borrow, and indeed have been borrowing on world capital markets for years.

But there are nevertheless some barriers to having the component states conduct differential fiscal policy. As said above, the small size of the EU budget implies there can be no EU-wide tax-transfer system for risk-sharing. There is no automatic response to shocks that hit some parts of the EU more than others, and no centralized income tax that will automatically absorb less from countries that are in recession and more from countries that are booming. Nor is there a centralized unemployment insurance scheme that could provide differential help to those countries with relatively high unemployment.

Given the resistance of the EU countries toward an EU-wide income tax, Goodhart and Smith (1993) have put forward a proposal for an insurance mechanism that would allow for stabilization against temporary differential shocks. Their proposal would involve temporary 
additional fiscal contributions from countries that are experiencing booms and additional disbursements to countries in recession, with little long-term redistribution of income between countries. In contrast to a central income tax, such a system would not protect against permanent shocks, and there would seem to be serious definitional problems regarding whether a country is in recession (hence qualifying for outside assistance) or in a boom (having an obligation to give outside assistance).

The Maastricht Treaty is an even more serious bar. To protect fiscal integrity, Maastricht required the member states of the EU to reduce deficits to 3 percent of GDP and public debt ratios to 60 percent of GDP. At the time, few of the states were close to these targets, and all have taken significant restrictive actions to come into compliance. Moreover, the Commission critiques the medium-term plans for fiscal deficits under the Stability and Growth Pact. Until now, the emphasis has been definitely on bringing states into compliance with these targets.

Provisions in the Stability and Growth Pact allow a country to have a temporary deficit above the 3 percent ceiling without sanction if the country's GDP declines by at least 2 percent in the relevant year. In addition, the Council is allowed to grant an exception if a country's GDP declines by from 0.75 to 2 percent in the relevant year. Even so, the joint supervision of fiscal policies based on actual budget balances tends to create incentives for national governments to tighten fiscal policy when a slowdown reduces revenues.

Given this past emphasis, there seems to be no problem with counter-cyclical fiscal policy in response to booming demand. Countries could simply tighten their fiscal policy and move further away from their Maastricht limits, with the Commission unlikely to object. The serious problem is on the other side: What happens if a country sees a recession coming and tries to ease fiscal policy differentially? 
It could accomplish such expansionary fiscal policy in at least three ways. One, not satisfactory to anybody, is for the recession to be so serious that the escape clauses are invoked. Second, the country could apply for a waiver to deviate from the targets it has set. A third, by far the most preferred in the long run, is for the country to reduce deficits and debt to levels well below the Maastricht limits, and then develop some "cap room." The country could simply incorporate its fiscal plans into its medium term report, and follow through.

As shown in the table 2 below, a few of the EMU countries have projected budget surpluses and thus room for fiscal flexibility, while others expect to open up some "cap room" over the next few years. For both Belgium and Italy, government debt relative to GDP is expected to remain well above the 60 percent Maastricht upper limit through 2003. However, both countries have reduced their debts significantly over the past few years and expect to make further progress in the medium term, so they are not considered to be in violation of that criterion. 


\section{Table 2}

\section{Projections in the 2000 Stability Programs}

(as a percent of GDP)

\begin{tabular}{|c|c|c|c|c|c|c|c|c|}
\hline \multirow[b]{2}{*}{ Country } & \multicolumn{4}{|c|}{$\begin{array}{l}\text { General Government Surplus } \\
(\text { Maastricht Limit }=\mathbf{- 3 \%})\end{array}$} & \multicolumn{4}{|c|}{$\begin{array}{c}\text { Debt } \\
(\text { Maastricht Limit }=60 \%)\end{array}$} \\
\hline & 2000 & 2001 & 2002 & 2003 & 2000 & 2001 & 2002 & 2003 \\
\hline Austria & -1.7 & -1.5 & -1.4 & -- & 62.2 & 61.2 & 60.0 & -- \\
\hline Belgium & -1.0 & -0.5 & 0.0 & 0.2 & 112.4 & 108.8 & 105.0 & 101.3 \\
\hline Finland & 4.7 & 4.2 & 4.6 & 4.7 & 42.9 & 40.7 & 38.0 & 35.2 \\
\hline France & -1.7 & -1.3 & -0.9 & -0.3 & 59.4 & 59.0 & 58.1 & 57.2 \\
\hline Germany & -1.0 & -1.5 & -1.0 & -0.5 & 61.0 & 60.5 & 59.5 & 58.5 \\
\hline Ireland & 1.2 & 2.5 & 2.6 & -- & 46.0 & 40.0 & 36.0 & -- \\
\hline Italy & -1.5 & -1.0 & -0.6 & -0.1 & 111.7 & 108.5 & 104.3 & 100.0 \\
\hline Luxembourg & 2.5 & 2.6 & 2.9 & 3.1 & 4.3 & 4.3 & 4.3 & 4.3 \\
\hline Netherlands & -0.6 & -1.3 & -1.1 & -- & 62.3 & 61.8 & 61.0 & -- \\
\hline Portugal & -1.5 & -1.1 & -0.7 & -0.3 & 57.1 & 55.2 & 53.3 & 51.0 \\
\hline Spain & -0.8 & -0.4 & 0.1 & 0.2 & 62.8 & 60.6 & 58.1 & 55.8 \\
\hline
\end{tabular}

Source: ECB Monthly Bulletin, March 2000. 
The projections in the 2000 stability programs show that the EU member countries anticipate a gradual reduction in their fiscal deficits and debts relative to GDP over the next few years, although only about half expect to be in surplus by 2003. According to the Commission, however, most of the projected improvement will come from anticipated strong growth and reductions in interest payments, with no significant progress in the cyclically-adjusted primary balance.

The fact that the EU has emphasized conformity in fiscal policy, along with the fact that the deficit targets are set in terms of actual deficits and that countries have developed only limited cap room, could do more than prevent fiscal stabilization. It could actually encourage procyclical fiscal policies. Suppose a country is near the Maastricht deficit limit when growth slows. The slowdown will tend to lower tax revenues, raise deficits, and force spending cutbacks, hence aggravating the slowdown. If the growth slowdown is not shared across the euro zone, this problem is compounded by the fact that interest rates are set centrally, hence eliminating any automatic monetary stabilizers.

How serious is this problem? If policy were pro-cyclical, as actual output falls relative to potential (making the output gap more negative), fiscal policy would be getting more contractionary (raising the structural budget surplus). Hence there would be a negative correlation between changes in output gaps and changes in structural budget surpluses. Table 3 shows data for ten countries in the euro zone, pre- and post-Maastricht. It also shows comparable data for five other countries, and with the correlations done for both actual and structural budget surpluses. The table suggests several points: 
- For almost all countries there is a vast difference between the actual and structural correlations, indicating that automatic fiscal stabilizers are alive and well, pre-and postMaastricht, inside and outside of the EMU area.

- For all euro area countries the correlation between output gaps and actual budget surpluses is positive in the post-Maastricht era, indicating that the automatic fiscal stabilizers do still work for most of these countries. Indeed, for all countries except Finland the correlations have become more positive since Maastricht, indicating that, for whatever reason, automatic fiscal stabilizers seem to work better than before in these countries. Note that the same is not true for the comparison countries at the bottom of the table.

- For all euro zone countries but Finland and Austria, the structural correlations in the postMaastricht period have gotten less negative, indicating again that, for whatever reason, Maastricht seems to be generating discretionary fiscal policies that are less pro-cyclical than before.

- But even if Maastricht itself is absolved from blame, the fact remains that in all euro zone countries but France and Spain, and all comparison countries, the structural correlations are now either negative or close to zero, so there is not much discretionary counter-cyclical fiscal policy anywhere. 
Table 3

\section{Correlations between Changes in Output Gaps and Changes in Fiscal Surpluses}

\begin{tabular}{lcccc}
\hline & \multicolumn{2}{c}{ Actual Surpluses } & \multicolumn{2}{c}{ Structural Surpluses } \\
\hline & $\begin{array}{l}\text { Pre-Maastricht } \\
(1983-92)\end{array}$ & $\begin{array}{c}\text { Post-Maastricht } \\
(1993-99)\end{array}$ & $\begin{array}{c}\text { Pre-Maastricht } \\
(1983-92)\end{array}$ & $\begin{array}{c}\text { Post-Maastricht } \\
(1993-99)\end{array}$ \\
\hline Germany & -0.85 & 0.55 & -0.86 & 0.03 \\
France & 0.76 & 0.88 & 0.16 & 0.55 \\
Italy & -0.05 & 0.29 & -0.42 & 0.00 \\
Netherlands & 0.14 & 0.15 & -0.39 & -0.17 \\
Spain & 0.69 & 0.89 & 0.26 & 0.92 \\
Portugal & -0.13 & 0.41 & -0.31 & 0.26 \\
Belgium & 0.23 & 0.70 & -0.25 & 0.20 \\
Ireland & 0.04 & 0.49 & -0.33 & 0.10 \\
Austria & -0.20 & 0.15 & -0.10 & -0.21 \\
Finland & 0.62 & 0.42 & 0.59 & -0.16 \\
& & & & -0.03 \\
United States & 0.65 & 0.20 & 0.60 & 0.19 \\
Canada & 0.84 & 0.52 & 0.18 & 0.06 \\
Japan & 0.17 & 0.31 & -0.14 & -0.23 \\
United Kingdom & 0.58 & -0.22 & 0.62 & 0.13 \\
Sweden & 0.79 & 0.33 & 0.29 & \\
\hline
\end{tabular}

Data Source: OECD, June 2000. 
Even though country data do not suggest a serious pro-cyclical problem at this point, there is a rather simple way around the potential problem. Eichengreen (1996) has suggested that the deficit limits be applied to structural, and not actual, deficit levels. This simple change would eliminate the destabilizing bias toward pro-cyclical fiscal policies. One drawback to Eichengreen's suggestion is the difficulty of estimating potential output, which would be necessary to calculate structural budget balances. If national governments were charged with estimating their own potential output, there could be concerns that they would overstate potential output to make budget deficits look more cyclical than structural. On the other hand, if a central body were to estimate potential output, there would be criticism that national governments would be forced to alter fiscal policy in response to the calculations of anonymous bureaucrats. In fact, the OECD, IMF, and national governments frequently come up with divergent estimates of structural budget balances.

\section{Monetary Policy}

Since the EMU is in effect creating a joint central bank from the central banks of eleven previously independent countries, it makes sense to look at how this has been accomplished. As described in some detail by Bertaut and Iyigun (1999), monetary policy in the euro area is conducted by the Eurosystem. This Eurosystem comprises the European Central Bank (ECB) at its center, along with the eleven national central banks. The Maastricht Treaty confers upon the Eurosystem as a whole most normal responsibilities of a central bank: defining and implementing monetary policy in the euro area, conducting foreign exchange operations, holding and managing official reserves, promoting the smooth operation of payment systems, and issuing banknotes and coins. In addition, the Eurosystem is expected to contribute to policies relating to 
the prudential supervision and stability of the financial system and to collect relevant statistical information.

The Eurosystem is structured much like the U.S. Federal Reserve System. The ECB has the responsibility to make sure that all of these central banking tasks are carried out, either on its own or by the national central banks. Decisions regarding monetary policy, interest rates and monetary growth, are set by the Governing Council (GC) of the ECB, composed of the eleven national central bank governors as well as six members of the executive committee. The primary responsibility of this executive board is to implement monetary policy and issue instructions to the national central banks, in accordance with the guidelines of the GC.

The euro area has adopted a form of inflation targeting to guide the conduct of monetary policy. As specified in the Maastricht Treaty, the primary objective of the ECB is to "maintain price stability," defined as a change of 2 percent or less in the published harmonized consumer price index. To bring this about, the GC considers the growth in euro-area monetary aggregates, along with a mix of other indicators that give a "broadly based assessment of the outlook for future price developments." This mix includes wages, bond rates, the yield curve, measures of real activity, business and consumer confidence, and euro exchange rates.

The ECB's focus in setting monetary policy is on area-wide price developments, not on conditions in individual countries. Discussion in the ECB Monthly Bulletin is in terms of areawide developments, and the ECB itself publishes only area-wide statistics. Although ECB officials sometimes comment on conditions in individual countries, such comments are in terms of how policy is likely to be set for the euro area as a whole, with the tacit assumption that fiscal policy (or something outside of the common monetary policy) is left to deal with differential conditions in individual countries. 
The Eurosystem has the authority to make decisions about intervention in the foreign exchange market and to conduct those operations. The ECB can conduct foreign exchange operations using its own reserves, or it can instruct the national central banks (who hold the bulk of the foreign exchange reserves) to do so on the Eurosystem's behalf. However, as stated in the ECB Monthly Bulletin (October 2000), "with regard to the overall framework within which exchange rate policy is conducted, the Treaty [establishing the European Community] provides for close interaction between the ECB and the EU Council." In particular, the Council can, after consultation with the ECB or upon recommendation of the ECB, formulate "general orientations for exchange-rate policy" (according to Article 111 (2) of the Treaty).

The more operational aspects of monetary policy - the execution of open market operations, administration of standing facilities, and reserve requirements are conducted by the national central banks. Access to the standing facilities is granted by the national central banks in their own countries. Credit institutions must also submit bids for refinancing operations to their own national central banks.

Some administrative arrangements reflect prior differences. For example, the ECB designates collateral required for its operations in two tiers. Tier one includes marketable eurodenominated debt instruments that fulfill area-wide eligibility specified by the ECB. Tier two consists of additional marketable and non-marketable assets of particular importance to national banking systems. The establishment of two tiers of eligible collateral reflects eligibility differences across the national central banks. In these and some other matters the ECB decided that full harmonization of practices before the start of the monetary union was neither practical nor desirable.

Prudential supervision is also conducted in a decentralized fashion. There is no uniform standard determining which agency has supervisory responsibilities within the euro area. In 
Ireland, Italy, the Netherlands, Portugal, and Spain, the national central bank has exclusive supervisory responsibility. In Belgium, Finland, and Luxembourg, the central bank has no specific supervisory responsibilities. In Austria, France, and Germany the central bank is extensively involved in supervision, though the explicit supervisory authority is either another branch of the government or an autonomous public institution. Although most prudential regulations are harmonized within the EU and supervisory roles remain at the national level, the ECB has seen the need for more coordination, and to this end established the Banking Supervision Committee in 1999. The mandate of this committee is to promote cooperation on issues of common interest to banking supervisors within the EU, and to assist in the preparation of ECB opinions on draft legislation regarding banking supervision and financial stability.

\section{Conclusion}

The EU represents an interesting case study for examining some of the postulates of fiscal federalism. Rather than dividing up responsibilities between the central and local governments, the EU was formed by a number of countries coming together to harmonize monetary and certain fiscal policies.

The EU fits naturally into federalism orthodoxy regarding spending policies. Because the central authority is formed from national governments without independent political authority, central spending in the EU will most likely remain low, as suggested by federalist teachings. On the tax side, however, rather than having large common taxes to reduce migration incentives, the EU is working gradually to harmonize the taxes assessed by national governments on mobile factors. Time will tell whether harmonized national tax rates work as well as centralized taxation in limiting migration incentives, and other inefficiencies. 
The EU has worked successfully to centralize monetary policy and harmonize interest rates. Simultaneously it has tried to enforce badly-needed fiscal discipline on its member states. Such a strategy should work fine as long as there are not disparate recessionary shocks in some countries. If there are, these countries could in principle combat the shocks through differentially expansionary fiscal policy, but only up to the limits provided by various EU agreements. Again, time will tell whether these limits impede stabilizing fiscal policy.

On the whole, the EU has successfully negotiated a complicated transition to harmonized tax and monetary policies. Inevitably, a few issues are left in the wake, and it will be interesting to see whether these issues become important as time passes. 


\section{References}

Bertaut, Carol C. and Murat F. Iyigun (1999), “The Launch of the Euro,” Federal Reserve Bulletin.

Eichengreen, Barry (1996), "Saving Europe's Automatic Stabilizers," National Institute Economic Review.

Eichengreen, Barry and Jurgen von Hagen (1996), "Fiscal Policy and Monetary Union: Is There a Tradeoff Between Federalism and Budgetary Restrictions?" Working Paper 5517, National Bureau of Economic Research.

Eichengreen, Barry and Charles Wyplosz (1997), "The Stability Pact: More than a Minor Nuisance?" unpublished manuscript, University of California, Berkeley.

European Commission (1996), “Taxation in the European Union," unpublished manuscript.

European Commission (2000), "Public Finances in EMU-2000," Report of the Directorate General for Economic and Financial Affairs.

Goodhart, Charles and Stephen Smith (1993), "Stabilization" in Section V on "Macrostabilization and shock absorption" of Reports and Studies on the Economics of Community Public Finance, European Economy, No.5, pp. 417-456.

Hoeller, Peter, Marie-Odile Louppe and Patrice Vergriete (1996), "Fiscal Relations within the European Union," Economics Department Working Papers No. 163, Organization for Economic Co-operation and Development.

Inman, Robert P. and Daniel L. Rubinfeld (1998), "Subsidiarity and the European Union," Working Paper No. 6556, National Bureau of Economic Research.

Kletzer, Kenneth M. (1997), "Macroeconomic Stabilization with a Common Currency: Does European Monetary Unification Create a Need for Fiscal Insurance or Federalism?" unpublished manuscript, University of California, Santa Cruz.

Persson, Torsten, Gerard Roland and Guido Tabellini (1996), “The Theory of Fiscal Federalism: What Does it Mean for Europe?" unpublished manuscript, prepared for the conference "Quo Vadis Europe?", Kiel, June 1996.

Zimmermann, Klaus F. (1995), "Tackling the European Migration Problem," Journal of Economic Perspectives, Volume 9, Number 2, pp. 45-62. 